\title{
Determinants of food quality perception and their relationships to physico-chemical characteristics: an application to meat
}

J. E. B. M. Steenkamp and J. C. M. van Trijp (Department of Marketing and Marketing Research, Wageningen Agricultural University, Hollandseweg 1, NL 6706 KN Wageningen, Netherlands)

Received 7 June 1988; accepted 5 October 1988

\begin{abstract}
A consumer-oriented approach to quality improvement can assist firms in the agribusiness to sustain their profitability. A model of the food-quality perception process of consumers has been developed that can be used by firms to implement such a consumer-oriented quality strategy. An empirical study was conducted for meat to explore the relationships between the variables in the model. Consumers' perceptions of quality can be meaningfully related to the physico-chemical characteristics of the meat cuts. Furthermore, consumers are willing to pay more for better quality meat.
\end{abstract}

Key words: quality perception, consumer behaviour, food products, agricultural products, meat, willingness to pay

Introduction. There is a distinct trend amongst consumers to become more demanding about food quality. If agribusiness companies are to be successful in the market, their quality strategy should link up with this consumer trend. This can only be achieved if producers adopt a consumer-oriented approach, as ultimately the consumer decides which food products to buy. The consumer's decision is largely determined by the way he or she perceives the quality of the product alternatives. On the other hand, products of consistent good quality have to be actually produced. This requires that the quality criteria used by consumers be translated into physico-chemical product specifications that can be used to control the production process. The present study is an investigation into the way consumers evaluate meat quality, and it relates consumer perceptions to physico-chemical product properties for four meat cuts.

Model. A model for the formulation of consumer quality perception has been developed (Fig. 1). It is an extension and elaboration of a model described by Steenkamp et al. (1986). At the point of purchase, the consumer's evaluation of quality is based on intrinsic and extrinsic quality indicators. Intrinsic quality indicators are part of the actual physical product. Extrinsic quality indicators are product-related but they are not actually a part of the physical product. Intrinsic quality indicators are 


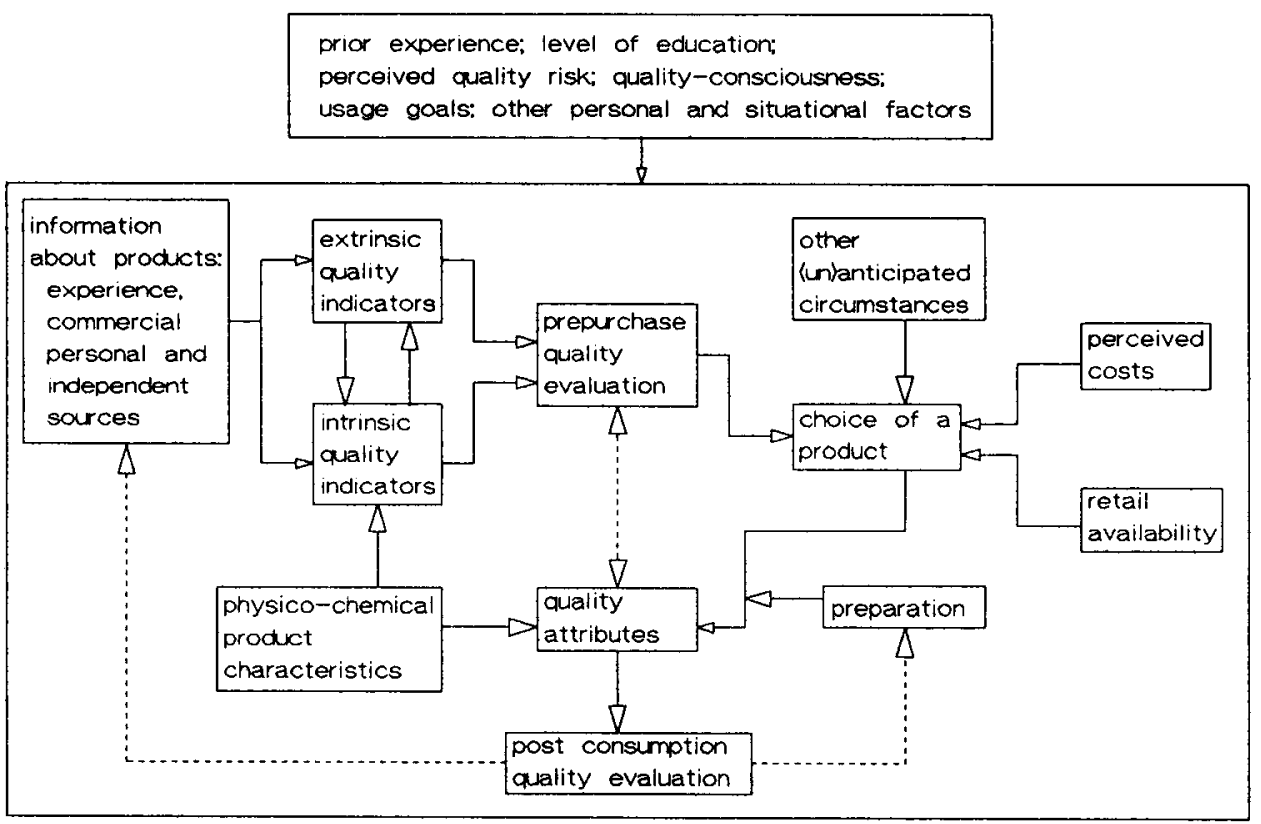

Fig. 1. A model for the formation of quality perceptions about food products.

mostly determined by the production process whereas extrinsic quality indicators are predominantly determined by marketing policy. The present study considers the relationships between consumers' perceptions of quality and the physico-chemical product characteristics. Therefore, only intrinsic quality indicators are included. In the choice process at the point of purchase, the consumer trades off perceived quality against price.

After a product alternative is purchased and consumed, the consumer can form a quality judgement based on the quality attributes. Quality attributes are product aspects that can only be evaluated after consumption, e.g. taste or tenderness. These quality attributes are the utility-generating characteristics of the product. The consumer's experience of the quality attributes leads to to some degree of satisfaction/dissatisfaction that will influence future purchasing behaviour.

Both the intrinsic quality indicators and the quality attributes are influenced by the physico-chemical characteristics of the product. As such, a firm can influence consumer perceptions of quality by modifying the physico-chemical characteristics of its product.

Materials and method. Data for the different phases of the model were obtained for a representative sample $(n=384)$ of the total Dutch consumer market for foreroast ( $m$. triceps brachee), pork rib-chop, blade steak and sirloin steak. Half of the sample was asked to evaluate the two pork cuts, while the other half participated in 
the evaluation of the two beef cuts. Real product samples were used in the evaluation. Each respondent evaluated one sample of each of the two meat cuts (either beef or pork), both in the raw state and after consumption (cooked by a professional chef). In the raw condition, representing the situation at the point of purchase, the meat samples were evaluated on a number of intrinsic quality indicators and overall perceived quality. After consumption, the same meat samples were evaluated on quality attributes and overall perceived quality. The physico-chemical meat characteristics were measured by researchers of the Research Institute for Animal Production 'Schoonoord' at Zeist. Twenty characteristics were distinguished for the pork cuts and twenty-one characteristics for the beef cuts. They are the characteristics commonly used to measure meat quality instrumentally.

Results. Table 1 contains the significant correlation coefficients $(P<0.01)$ between the rating of a meat sample on a quality attribute and its rating on overall perceived quality. The size of the correlation coefficient is a measure of the relative importance of that attribute in the evaluation of overall quality after consumption. Although some differences do exist between meat cuts, Table 1 clearly reveals that 'taste' and 'tenderness' are the two most important quality attributes. Meat cuts that have a pleasant taste and that are tender are judged to be of high quality. Carvability and juiciness are also of considerable importance. Firmness, colour, fatiness and smell are less important.

Table 2 contains the correlation coefficients of the meat cuts in the raw condition. It is clear that the quality perception of the meat cuts at the point of purchase is mainly based on the general appearance of the product. Visible fat (including fatty edges and amount of intramuscular fat) is also of great importance. Freshness is of particular importance to the quality perception of fore-roast, a fact that deserves the attention of supermarkets and butchers.

The relationships between consumer perceptions of a meat sample on intrinsic quality indicators and attributes, and the physico-chemical characteristics of the sample differ considerably between meat cuts. Given the large number of physicochemical characteristics measured, it is not practicable to report all results in detail

Table 1 . Significant correlations $(P<0.01)$ between quality attributes and overall perceived quality after consumption for four meat cuts.

\begin{tabular}{lllll}
\hline Quality attribute & Fore-roast & Pork rib chop & Blade steak & Sirloin steak \\
Colour & - & 0.19 & - & - \\
Smell & 0.39 & - & 0.36 & 0.24 \\
Taste & 0.63 & 0.59 & 0.63 & 0.50 \\
Tenderness & 0.58 & 0.67 & 0.59 & 0.80 \\
Carvability & 0.41 & 0.49 & 0.42 & 0.55 \\
Juiciness & 0.50 & 0.42 & 0.48 & 0.38 \\
Firmness & 0.28 & 0.24 & 0.21 & - \\
Amount of sinews/tendons & 0.43 & 0.19 & 0.45 & 0.44 \\
Fatiness & 0.35 & 0.26 & 0.37 & - \\
\hline
\end{tabular}


Table 2. Significant correlations $(P<0.01)$ between intrinsic quality indicators and overall perceived quality at point of purchase for four meat cuts.

\begin{tabular}{lcccc}
\hline Intrinsic quality indicator & Fore-roast & Pork rib chop & Blade steak & Sirloin steak \\
Colour intensity & -0.35 & -0.26 & 0.25 & - \\
Colour variation & -0.38 & -0.27 & -0.28 & -0.22 \\
Moistness & - & - & - & - \\
Freshly cut & 0.56 & 0.24 & 0.34 & 0.34 \\
Size of the fatty edges & -0.37 & -0.40 & -0.26 & n.a. \\
Amount of intramuscular fat & -0.33 & -0.45 & -0.44 & n.a. \\
Thickness & - & - & - & - \\
General appearance & 0.67 & 0.58 & 0.63 & 0.60 \\
Freshness & 0.42 & 0.22 & 0.35 & 0.36 \\
Amount of bone & n.a. & -0.19 & n.a. & n.a. \\
\hline
\end{tabular}

${ }^{1}$ n.a. = not applicable for this meat cut

here. However, six characteristics were found common to most of the meat cuts: $\mathrm{pH}$, visual colour evaluation on the Japanese scale, drip loss, cooking loss, marbling score and sarcomere length (the latter measure only applicable to beef cuts) are most relevant when related to consumer perceptions. The results for these six characteristics are summarized in Table 3 . Note that only the most important indicators and attributes are included in this table. Quality improvement through animal breeding, feeding and slaughtering programmes should preferably start with the modification of these characteristics as their goal. It was concluded that the use of expert panels can be helpful in relating the physico-chemical characteristics of meat to consumer perceptions.

Quality improvement is especially attractive to firms if higher prices can be charged for the better-quality products. Consumers' willingness to pay for better quality was investigated using the method of Gabor-Granger (1966). With the exception of fore-roast, respondents showed a willingness to pay more for better quality. Three consumer characteristics influence the willingness to pay. The degree of quality-consciousness exerted a significant influence on the willingness to pay for fore-roast, pork rib chop and sirloin steak. Other consumer characteristics that influence willingness to pay were age (for fore-roast) and frequency of consumption (for both beef cuts).

Conclusions. Adjusting product quality to consumers' needs is an important means to retain or even increase a firm's market share, but also to obtain better prices for one's product. As it is the consumer who ultimately decides which product to buy, it is essential to study quality from the point of view of the consumer. Using this as a starting point, technical standards can be formulated that should be met during production. The approach presented above helps link quality perceptions to objective product standards. In this way, quality-perception research can provide guidance for consumer-oriented product development. 
Table 3. Significant correlations ( $P<0.05$; two-sided) between quality attributes/quality indicators and selected physico-chemical characteristics for four different meat cuts.

\begin{tabular}{|c|c|c|c|c|c|c|c|}
\hline Fore roast & & Pork rib chol & & Blade steak & & Sirloin steak & \\
\hline pH-average & & & & & & & \\
\hline $\begin{array}{l}\text { sinews/tendons } \\
\text { freshness }\end{array}$ & $\begin{array}{l}-0.19 \\
-0.17\end{array}$ & $\begin{array}{l}\text { juiciness } \\
\text { appearance } \\
\text { taste }\end{array}$ & $\begin{array}{r}0.19 \\
-0.17 \\
0.15\end{array}$ & $\begin{array}{l}\text { appearance } \\
\text { sinews/tendons }\end{array}$ & $\begin{array}{l}-0.21 \\
-0.16\end{array}$ & & \\
\hline pH-range & & & & & & & \\
\hline $\begin{array}{l}\text { appearance } \\
\text { freshly cut }\end{array}$ & $\begin{array}{l}-0.20 \\
-0.19\end{array}$ & & & $\begin{array}{l}\text { carvability } \\
\text { sinews/tendons } \\
\text { tenderness }\end{array}$ & $\begin{array}{l}-0.17 \\
-0.16 \\
-0.15\end{array}$ & & \\
\hline Colour (Japanese & cale) & & & & & & \\
\hline $\begin{array}{l}\text { sinews/tendons } \\
\text { freshly cut }\end{array}$ & $\begin{array}{l}-0.28 \\
-0.16\end{array}$ & $\begin{array}{l}\text { juiciness } \\
\text { taste }\end{array}$ & $\begin{array}{l}0.15 \\
0.14\end{array}$ & & & & \\
\hline Drip loss & & & & & & & \\
\hline $\begin{array}{l}\text { sinews/tendons } \\
\text { freshness } \\
\text { freshly cut }\end{array}$ & $\begin{array}{l}0.19 \\
0.19 \\
0.17\end{array}$ & & & & & $\begin{array}{l}\text { carvability } \\
\text { tenderness }\end{array}$ & $\begin{array}{l}0.21 \\
0.16\end{array}$ \\
\hline $\begin{array}{l}\text { Cooking loss } \\
\text { sinews/tendons } \\
\text { freshly cut } \\
\text { freshness }\end{array}$ & $\begin{array}{l}0.17 \\
0.16 \\
0.15\end{array}$ & $\begin{array}{l}\text { fatty edges } \\
\text { tenderness } \\
\text { appearance } \\
\text { carvability }\end{array}$ & $\begin{array}{r}0.20 \\
-0.19 \\
0.16 \\
-0.15\end{array}$ & & & & \\
\hline $\begin{array}{c}\text { Marbling } \\
\text { taste }\end{array}$ & -0.17 & $\begin{array}{l}\text { fatty edges } \\
\text { amount fat }\end{array}$ & $\begin{array}{l}-0.21 \\
-0.15\end{array}$ & $\begin{array}{l}\text { tenderness } \\
\text { carvability }\end{array}$ & $\begin{array}{l}-0.20 \\
-0.16\end{array}$ & & \\
\hline $\begin{array}{l}\text { Sarcomere length } \\
\text { n.a. }{ }^{1}\end{array}$ & & n.a. & & $\begin{array}{l}\text { tenderness } \\
\text { carvability } \\
\text { sinews/tendons }\end{array}$ & $\begin{array}{l}0.26 \\
0.26 \\
0.16\end{array}$ & & \\
\hline
\end{tabular}

${ }^{1}$ n.a. $=$ this physico-chemical characteristic is not applicable for this meat cut.

\section{References}

Gabor, A. \& C. W. Granger, 1966. Price as an indicator of quality: report on an enquiry. Economica 33: 43-70.

Steenkamp, J. E. B. M., B. Wierenga \& M. T. G. Meulenberg, 1986. Analysis of food quality perception processes. Netherlands Journal of Agricultural Science 34: 227-230. 
This synopsis is based on a report 'Sensorische kwaliteitsbeoordeling en bereidingsgewoonten vers vlees' by J. E. B. M. Steenkamp and J. C. M. van Trijp (Department of Marketing and Marketing Research, Wageningen Agricultural University). Report No 29, Produktschap voor vee en vlees, Postbus 5805, $2280 \mathrm{HV}$ Rijswijk, 1988. 308 pp., 26 figs., 113 tables, 29 refs. Available as paper copy (order R085P, $f 20$ including postage) at: NARD, clo Pudoc, P.O. Box 4, 6700 AA Wageningen, Netherlands (telex 45015 blhwg nl) 